\title{
Peningkatan Sains dan Kreativitas Masyarakat Melalui Budidaya Bawang Dayak Secara Organik dan Pengolahan Kompos Limbah Pasar Tradisional
}

\section{Improvement of Community Science and Creativity Through Organic Dayak Onion Cultivation and Traditional Market Waste Compost Processing}

\author{
Titin Apung Atikah ${ }^{*}$ \\ Muliansyah ${ }^{1}$ \\ Astri Widiarti ${ }^{2}$ \\ Pienyani Rosawanti ${ }^{3}$ \\ 1Department of Agriculture, \\ Universitas Palangka Raya, Palangka \\ Raya, Central Kalimantan, Indonesia \\ 2Department of Medicine, Universitas \\ Palangka Raya, Palangka Raya, \\ Central Kalimantan, Indonesia \\ ${ }^{3}$ Department of Agrotechnology, \\ Universitas Muhammadiyah \\ Palangkaraya, Palangka Raya, Central \\ Kalimantan, Indonesia
}

*email: titinapungatikah@ymail.com

\section{Kata Kunci}

Budidaya Organik

Limbah Pasar Tradisional

Peningkatan Sains dan Kreativitas

Pengolahan Kompos

Keywords:

Organic Cultivation

Traditional Market Waste

Enhancing Science and Creativity

Compost Processing

Received: September 2019

Accepted: November 2019

Published: December 2019

\begin{abstract}
Abstrak
Dewasa ini, adanya kecenderungan masyarakat untuk kembali ke pola hidup kembali ke alam dengan keyakinan bahwa mengkonsumsi obat alami relatif lebih aman dibanding dengan obat sintetik berdampak pada tingginya permintaan akan obat alami. Bawang dayak (Eleutherine palmifolia Merr.) merupakan salah satu jenis tanaman obat khas Kalimantan dimana dalam pemanfaatannya sebagai tanaman obat yang digunakan adalah umbinya yang dikonsumsi dalam bentuk air rebusan umbi segar maupun dalam bentuk simplisia. Kegiatan dengan metode pelatihan dan demontrasi/praktek menjadi salah satu solusi yang dapat dilakukan. Hasil kegiatan pengabdian kepada masyarakat didapatkan data bahwa semua peserta turut aktif dan dapat menerima semua pengetahuan dan ketrampilan yang di transfer oleh tim PKW dan berminat melakukan sendiri dirumah dimana produk hasil tanaman secara organik akan dikonsumsi sendiri (40\%) dan dijual $(60 \%)$ dengan produk olahan makanan dan minuman (55\%) dan bentuk obat tradisional (45\%). Demikian pula untuk kegiatan pengolahan kompos berbahan limbah pasar tradisional, hasil olahan kompos akan digunakan sendiri $(85 \%)$ dan dijual $(15 \%)$ dengan produk kompos berbahan limbah pasar $(80 \%)$ dan kompos berbahan lainnya $(20 \%)$ yang diminati. Data tersebut menunjukan bahwa Program kegiatan Pengabdian Kepada Masyarakat yang dilakukan mampu berkontribusi dan menjadi solusi untuk mengatasi permasalahan yang dihadapi mitra.
\end{abstract}

\begin{abstract}
Today, the tendency of people to return to life to return to nature with the belief that taking natural medicines is relatively safer than synthetic drugs has an impact on the high demand for natural medicines. Dayak onion (Eleutherine palmifolia Merr.) is one of the typical types of medicinal plants in Kalimantan wherein its use as a medicinal plant the tubers are consumed in the form of freshly boiled water or in the form of simplicia. Activities with training methods and demonstrations/practices are one of the solutions that can be done. The results of community service activities showed that all participants participated actively and could receive all the knowledge and skills transferred by the PKW team and were interested in doing it themselves at home where organic crop products would be consumed by themselves (40\%) and sold (60\%) with processed food and beverage products $(55 \%)$ and traditional forms of medicine $(45 \%)$. Likewise, for the processing of compost made from traditional market waste, compost processed products will be used alone $(85 \%)$ and sold $(15 \%)$ with compost products made from market waste $(80 \%)$ and other compost made from ingredients $(20 \%)$ of interest. The data shows that the Community Service Program conducted can contribute and be a solution to overcome the problems faced by partners.
\end{abstract}




\section{PENDAHULUAN}

Kecamatan Jekan Raya merupakan salah satu dari lima kecamatan di kota Palangka Raya. Terdiri atas empat kelurahan yaitu kelurahan Menteng, Palangka, Bukit Tunggal dan Petuk Katimpun. Kelurahan Petuk Katimpun memiliki luas wilayah 59,62 km² (15,39\%) (Badan Pusat Statistik Kota Palangka Raya, 2018), merupakan daerah pemukiman penduduk yang masih belum terlalu padat dengan luasan pekarangan masingmasing rumah tangga cukup luas. Jenis tanah didominasi jenis tanah berpasir (entisol) (Firmansyah et al., 2008), $\mathrm{pH}$ tanah rendah (masam), memiliki pori-pori yang besar (lebih porous), serta rendahnya kandungan unsur hara makro dan mikro akibat adanya proses pencucian dan penguapan (Surianto et al., 2015).

Beberapa jenis tanaman yang ditanam masyarakat setempat dianggap dapat tumbuh dan beradaptasi dengan faktor lingkungan setempat. Tanaman Bawang Dayak merupakan salah satu jenis tanaman obat yang dapat tumbuh dan menjadi sumber pendapatan masyarakat (Naspiah et al., 2014). Berdasarkan hasil penelitian Atikah et al. (2017) menemukan bahwa jenis tanah berpasir di Petuk Katimpun merupakan media tanah yang cocok untuk pertumbuhan dan hasil bawang dayak. Teknologi dengan budidaya secara organik akan lebih menjamin dihasilkannya bahan herbal yang sehat dan aman dari kontaminasi unsur-unsur kimia berbahaya (Setyawan et al., 2019). Kendala yang dihadapi oleh petani bawang dayak di lokasi sasaran adalah selain perlunya teknologi budidaya organik untuk menjamin hasil produk komoditas tanaman obat yang aman dan sehat juga perlu adanya kegiatan pengolahan kompos berbahan limbah untuk menunjang kesuburan tanah.

Berdasarkan hasil wawancara dengan beberapa warga masyarakat, mereka menghendaki perlu adanya peningkatan pengetahuan tentang teknologi budidaya secara organik, teknologi pembuatan kompos secara sederhana dari limbah rumah tangga/pasar tradisional, pengetahuan tentang manfaat tanaman umbi bawang dayak untuk kesehatan dan perlu adanya pelatihan tentang cara memilih bibit yang baik untuk dibudidayakan. Teknologi pembuatan kompos sederhana dari limbah rumah tangga/pasar tradisional merupakan alternatif untuk meningkatkan produktivitas kesuburan tanah dan mengurangi beban lingkungan akibat penumpukan sampah yang dapat menjadi sumber pencemaran lingkungan (Rezaei et al., 2010).

\section{METODOLOGI}

Kegiatan ini dilaksanakan selama empat bulan dimulai pada bulan Agustus hingga November 2019. Kegiatan Pengabdian berlokasi di Kelurahan Petuk Katimpun, Kecamatan Jekan Raya, Kota Palangka Raya, Provinsi Kalimantan Tengah.

Metode pendekatan yang dilakukan adalah meliputi pelatihan/penyuluhan, pendampingan, percontohan budidaya secara organik, pengolahan limbah rumah tangga/limbah pasar tradisional menjadi kompos dan tehnik pemilihan/seleksi umbi yang baik dijadikan bibit. Keterlibatan mitra pada kegiatan ini adalah dalam tahap kesempatan menentukan jenis tanaman obat yang akan dibudidayakan secara organik, menentukan waktu dan memanfaatkan limbah apa yang akan dijadikan kompos, menentukan peserta/mitra yang akan mengikuti kegiatan, menentukan waktu dan tampat pelaksanaan kegiatan serta berkoordinasi dengan pemangku dan instansi terkait di wilayah setempat. Pelaksanaan kegiatan Pelatihan serta penyuluhan dan demontrasi/praktek/demplot dilaksanakan bertempat di Jalan Petuk Katimpun Gang Anugerah RT.04/RW.02. Adapun jenis kegiatan pendampingan sesuai kesepakatan bersama untuk mengatasi permasalahan mitra adalah sebagai berikut: 
1. Pendampingan kegiatan budidaya tanaman bawang dayak secara organik dengan menggunakan pupuk kompos yang berasal dari limbah rumah tangga atau limbah pasar tradisional (Darmosarkoro et al., 2001).

2. Pelatihan pemanfaatan/pengolahan limbah rumah tangga atau limbah pasar tradisional menjadi kompos yang memberikan manfaat bagi peningkatan produktivitas tanah sekaligus mengurangi beban lingkungan (Rezaei et al., 2010).

3. Peningkatan pengetahuan masyarakat melalui cara seleksi umbi bibit bawang dayak yang baik untuk dibudidayakan (Atikah et al., 2017), manfaat umbi bawang dayak bagi kesehatan serta manfaat kandungan kimia umbi (Babula et al., 2005) serta pemanfaatan umbi bawang dayak sebagai tanaman obat khas Kalimantan Tengah (Pusat Studi Biofarmaka LPPM IPB \& Ulung, 2013).

Peran pihak Kelurahan Petuk Katimpun dalam hal ini lurah menyambut baik kegiatan yang akan dilaksanakan dengan menugaskan/merekomendasikan satu orang petugas/pegawai kelurahan untuk mendampingi pelaksanaan kegiatan sehingga kegiatan yang dilaksanakan ini terarah dan memberikan dampak positif bagi masyarakat.

Evaluasi kegiatan dilakukan pada akhir kegiatan dengan melihat indikator keberhasilan demplot budidaya tanaman secara organik, meningkatnya jumlah masyarakat yang berpartisipasi serta meningkatnya pengetahuan masyarakat tentang materi pelatihan dan pengolahan yang disampaikan

\section{HASIL DAN PEMBAHASAN}

Pelatihan dan demontrasi/praktek budidaya tanaman bawang dayak secara organik serta Pengolahan kompos berbahan limbah pasar tradisional/limbah rumah tangga sangat diminati oleh peserta/mitra sasaran, hal ini dapat terlihat dari peran aktif selama kegiatan serta kemampuan menerima dan menerapkan pengetahuan dan ketrampilan yang sudah ditransfer. Hasil setelah melaksanakan kegiatan pengabdian didapatkan bahwa semua peserta $(100 \%)$ turut aktif dan dapat menerima semua pengetahuan dan ketrampilan yang disampaikan oleh tim PKW dan berminat melakukan sendiri dirumah (100\%) dimana hasil produk budidaya secara organik akan dikonsumsi sendiri (40\%) dan dijual (60\%) dengan produk olahan umbi bawang dayak diolah menjadi makanan dan minuman (55\%) dan obat tradisional (45\%). Demikian pula untuk kegiatan pengolahan kompos berbahan limbah pasar tradisional/limbah rumah tangga dimana hasil olahan kompos akan digunakan sendiri $(85 \%)$ dan dijual $(15 \%)$ dengan produk kompos berbahan limbah pasar (80\%) dan kompos berbahan lainnya (20\%) yang diminati. Adapun data-data yang diperoleh dari hasil kegiatan pengabdian kepada masyarakat disajikan pada Tabel I sampai Tabel IV berikut:

Tabel I. Daftar quisioner dan jawaban peserta pelatihan dan demontrasi/praktikum Budidaya tanaman bawang dayak secara organik yang dilakukan sebelum kegiatan.

\begin{tabular}{|c|c|c|c|c|}
\hline \multirow{2}{*}{ No } & \multirow{2}{*}{ Pertanyaan } & \multicolumn{3}{|c|}{ Jawaban } \\
\hline & & Pilihan 1 & Pilihan 2 & Pilihan 3 \\
\hline 1. & $\begin{array}{l}\text { Apakah } \\
\text { ibu/sdr } \\
\text { pernah } \\
\text { melakukan } \\
\text { budidaya } \\
\text { tanaman } \\
\text { secara } \\
\text { organik? }\end{array}$ & $\begin{array}{l}\text { Sudah } \\
(45 \%)\end{array}$ & $\begin{array}{l}\text { Belum } \\
(55 \%)\end{array}$ & $\begin{array}{l}\text { Tidak } \\
\text { tahu } \\
(0 \%)\end{array}$ \\
\hline 2. & $\begin{array}{l}\text { Budidaya } \\
\text { secara } \\
\text { organik } \\
\text { terhadap } \\
\text { tanaman apa? }\end{array}$ & $\begin{array}{l}\text { Tanaman } \\
\text { sayuran } \\
(40 \%)\end{array}$ & $\begin{array}{l}\text { Tanaman } \\
\text { buahan } \\
(20 \%)\end{array}$ & $\begin{array}{l}\text { Lainnya } \\
(40 \%)\end{array}$ \\
\hline 3. & $\begin{array}{l}\text { Darimana } \\
\text { ibu/sdr } \\
\text { mendapatkan } \\
\text { bibit tanaman } \\
\text { selama ini? }\end{array}$ & $\begin{array}{l}\text { Membeli } \\
(55 \%)\end{array}$ & $\begin{array}{l}\text { Bibit hasil } \\
\text { menanam } \\
\text { sendiri } \\
(15 \%)\end{array}$ & $\begin{array}{l}\text { Lainnya } \\
(30 \%)\end{array}$ \\
\hline 4. & $\begin{array}{l}\text { Berapa kali } \\
\text { pernah } \\
\text { melaksanakan } \\
\text { budidaya } \\
\text { secara } \\
\text { organik? }\end{array}$ & $\begin{array}{l}\text { Setiap } \\
\text { hari }(15 \%)\end{array}$ & $\begin{array}{l}\text { Seminggu } \\
\text { sekali } \\
(15 \%)\end{array}$ & $\begin{array}{l}\text { Lainnya } \\
(70 \%)\end{array}$ \\
\hline
\end{tabular}




\begin{tabular}{|c|c|c|c|c|}
\hline 5. & $\begin{array}{l}\text { Pernahkah } \\
\text { ibu/sdr } \\
\text { memperoleh } \\
\text { pelatihan } \\
\text { tentang cara } \\
\text { budidaya } \\
\text { tanaman } \\
\text { bawang } \\
\text { dayak secara } \\
\text { organik? }\end{array}$ & $\begin{array}{l}\text { Belum } \\
(90 \%)\end{array}$ & $\begin{array}{l}\text { Sudah } \\
(10 \%)\end{array}$ & $\begin{array}{l}\text { Tidak } \\
\text { tahu } \\
(0 \%)\end{array}$ \\
\hline
\end{tabular}

Tabel II. Daftar quisioner dan jawaban peserta pelatihan dan demontrasi/praktik Budidaya bawang dayak secara organik yang dilakukan setelah kegiatan.

\begin{tabular}{|c|c|c|c|c|}
\hline \multirow{2}{*}{ No } & \multirow{2}{*}{ Pertanyaan } & \multicolumn{3}{|c|}{ Jawaban } \\
\hline & & Pilihan 1 & Pilihan 2 & Pilihan 3 \\
\hline 1. & $\begin{array}{l}\text { Apakah } \\
\text { kegiatan } \\
\text { pelatihan } \\
\text { yang } \\
\text { dilakukan } \\
\text { sudah } \\
\text { jelas? }\end{array}$ & $\begin{array}{l}\text { Sudah } \\
(100 \%)\end{array}$ & $\begin{array}{l}\text { Belum } \\
(0 \%)\end{array}$ & $\begin{array}{l}\text { Tidak } \\
\text { tahu }(0 \%)\end{array}$ \\
\hline 2. & $\begin{array}{l}\text { Apakah } \\
\text { berminat } \\
\text { melakukan } \\
\text { sendiri di } \\
\text { rumah? }\end{array}$ & Ya $(100 \%)$ & $\begin{array}{l}\text { Tidak } \\
(0 \%)\end{array}$ & $\begin{array}{l}\text { Lainnya } \\
(0 \%)\end{array}$ \\
\hline 3. & $\begin{array}{l}\text { Apakah } \\
\text { produk } \\
\text { budidaya } \\
\text { tanaman } \\
\text { bawang } \\
\text { dayak } \\
\text { secara } \\
\text { organik } \\
\text { tersebut } \\
\text { dijual atau } \\
\text { dikonsumsi } \\
\text { sendiri? }\end{array}$ & $\begin{array}{l}\text { Dikonsumsi } \\
\text { sendiri } \\
(40 \%)\end{array}$ & $\begin{array}{l}\text { Dijual } \\
(60 \%)\end{array}$ & $\begin{array}{l}\text { Lainnya } \\
(0 \%)\end{array}$ \\
\hline 4. & $\begin{array}{l}\text { Dari } \\
\text { produk } \\
\text { budidaya } \\
\text { bawang } \\
\text { dayak } \\
\text { secara } \\
\text { organik, } \\
\text { umbi } \\
\text { bawang } \\
\text { dayak } \\
\text { ingin } \\
\text { diolah } \\
\text { dalam } \\
\text { bentuk } \\
\text { apa? }\end{array}$ & $\begin{array}{l}\text { Makanan } \\
\text { dan } \\
\text { minuman } \\
(55 \%)\end{array}$ & $\begin{array}{l}\text { Obat } \\
\text { tradisional } \\
(45 \%)\end{array}$ & $\begin{array}{l}\text { Lainnya } \\
(0 \%)\end{array}$ \\
\hline
\end{tabular}

Tabel III. Daftar quisioner dan jawaban peserta pelatihan dan demontrasi/praktek Pengolahan kompos dari limbah pasar tradisional/limbah rumah tangga yang dilakukan sebelum kegiatan.

\begin{tabular}{|c|c|c|c|c|}
\hline \multirow{2}{*}{ No } & \multirow{2}{*}{ Pertanyaan } & \multicolumn{3}{|c|}{ Jawaban } \\
\hline & & Pilihan 1 & Pilihan 2 & Pilihan 3 \\
\hline 1. & $\begin{array}{l}\text { Apakah } \\
\text { ibu/sdr } \\
\text { pernah } \\
\text { melakukan } \\
\text { kegiatan } \\
\text { pengolahan } \\
\text { kompos? }\end{array}$ & $\begin{array}{l}\text { Sudah } \\
(20 \%)\end{array}$ & $\begin{array}{l}\text { Belum } \\
(75 \%)\end{array}$ & $\begin{array}{l}\text { Tidak } \\
\text { tahu (5\%) }\end{array}$ \\
\hline 2. & $\begin{array}{l}\text { Pengomposan } \\
\text { berbahan } \\
\text { limbah apa? }\end{array}$ & $\begin{array}{l}\text { Limbah } \\
\text { pertanian } \\
(25 \%)\end{array}$ & $\begin{array}{l}\text { Limbah } \\
\text { industri } \\
(0 \%)\end{array}$ & $\begin{array}{l}\text { Lainnya } \\
(75 \%)\end{array}$ \\
\hline 3. & $\begin{array}{l}\text { Darimana } \\
\text { ibu/sdr } \\
\text { mendapatkan } \\
\text { bahan limbah } \\
\text { kompos } \\
\text { tersebut? }\end{array}$ & $\begin{array}{l}\text { Membeli } \\
(20 \%)\end{array}$ & $\begin{array}{l}\text { Produk } \\
\text { sendiri } \\
(15 \%)\end{array}$ & $\begin{array}{l}\text { Lainnya } \\
(65 \%)\end{array}$ \\
\hline 4. & $\begin{array}{l}\text { Berapa kali } \\
\text { pernah } \\
\text { melakukan } \\
\text { pengomposan? }\end{array}$ & $\begin{array}{l}\text { Sebulan } \\
\text { sekali } \\
(10 \%)\end{array}$ & $\begin{array}{l}\text { Setahun } \\
\text { sekali } \\
(10 \%)\end{array}$ & $\begin{array}{l}\text { Lainnya } \\
(80 \%)\end{array}$ \\
\hline 5. & $\begin{array}{l}\text { Pernahkah } \\
\text { ibu/sdr } \\
\text { memperoleh } \\
\text { pelatihan } \\
\text { tentang cara } \\
\text { pengolahan } \\
\text { kompos dari } \\
\text { limbah pasar } \\
\text { tradisional? }\end{array}$ & $\begin{array}{l}\text { Belum } \\
(80 \%)\end{array}$ & $\begin{array}{l}\text { Sudah } \\
(20 \%)\end{array}$ & $\begin{array}{l}\text { Tidak } \\
\text { tahu }(0 \%)\end{array}$ \\
\hline
\end{tabular}

Tabel IV. Daftar quisioner dan jawaban peserta pelatihan dan demontrasi/praktek Pengolahan kompos dari limbah pasar tradisional/limbah rumah tangga yang dilakukan setelah kegiatan.

\begin{tabular}{|c|c|c|c|c|}
\hline \multirow{2}{*}{ No } & \multirow{2}{*}{ Pertanyaan } & \multicolumn{3}{|c|}{ Jawaban } \\
\hline & & Pilihan 1 & Pilihan 2 & Pilihan 3 \\
\hline 1. & $\begin{array}{l}\text { Apakah } \\
\text { kegiatan } \\
\text { pelatihan } \\
\text { yang } \\
\text { dilakukan } \\
\text { sudah jelas? }\end{array}$ & $\begin{array}{l}\text { Sudah } \\
(100 \%)\end{array}$ & $\begin{array}{l}\text { Belum } \\
(0 \%)\end{array}$ & $\begin{array}{l}\text { Tidak } \\
\text { tahu } \\
(0 \%)\end{array}$ \\
\hline 2. & $\begin{array}{l}\text { Apakah } \\
\text { berminat } \\
\text { melakukan } \\
\text { sendiri di } \\
\text { rumah? }\end{array}$ & Ya $(100 \%)$ & Tidak (0\%) & $\begin{array}{l}\text { Lainnya } \\
(0 \%)\end{array}$ \\
\hline 3. & $\begin{array}{l}\text { Apakah } \\
\text { produk } \\
\text { kompos } \\
\text { berbahan } \\
\text { limbah } \\
\text { pasar } \\
\text { tradisional/ } \\
\text { limbah } \\
\text { rumah }\end{array}$ & $\begin{array}{l}\text { Digunakan } \\
\text { sendiri } \\
(85 \%)\end{array}$ & $\begin{array}{l}\text { Dijual } \\
(15 \%)\end{array}$ & $\begin{array}{l}\text { Lainnya } \\
(0 \%)\end{array}$ \\
\hline
\end{tabular}




\begin{tabular}{|c|c|c|c|c|}
\hline 4. & $\begin{array}{l}\text { tangga } \\
\text { tersebut } \\
\text { dijual atau } \\
\text { digunakan } \\
\text { sendiri? } \\
\text { Dari semua }\end{array}$ & Kompos & Kompos & Lainnya \\
\hline & $\begin{array}{l}\text { produk, } \\
\text { kompos } \\
\text { mana yang } \\
\text { paling } \\
\text { diminati } \\
\text { untuk } \\
\text { dicoba? }\end{array}$ & $\begin{array}{l}\text { dari } \\
\text { limbah } \\
\text { pasar } \\
(80 \%)\end{array}$ & $\begin{array}{l}\text { dari } \\
\text { limbah } \\
\text { industri } \\
(0 \%)\end{array}$ & $(20 \%)$ \\
\hline
\end{tabular}

\section{KESIMPULAN}

Dari kegiatan pengabdian kepada masyarakat yang dilakukan oleh perguruan tinggi Universitas Palangka Raya beserta perguruan tinggi mitra (Universitas Muhammadiyah Palangkaraya), diketahui bahwa kegiatan yang dilakukan mampu berkontribusi dan menjadi solusi untuk mengatasi permasalahan yang sedang dihadapi mitra sasaran.

\section{UCAPAN TERIMA KASIH}

Ucapan terima kasih disampaikan kepada Bantuan PNBP yang memberikan dukungan pendanaan untuk kegiatan pengabdian kepada masyarakat pada tahun 2019, juga kepada LPPM UPR yang memberikan kesempatan untuk melaksanakan kegiatan pengabdian kepada masyarakat khususnya Program Kemitraan Wilayah serta Universitas Muhammadiyah Palangkaraya yang telah bersedia menjadi perguruan tinggi mitra.

\section{REFERENSI}

Atikah, T.A., Wardiyati, T., Nihayati, E., Saputera. 2017. The growth patterns and eleutherine content of dayak onion (Eleutherine palmifolia Merr.) in sandy mineral soil and peat soil. International Journal of Biosciences. 10(4):222-231. http://dx.doi.org/10.12692/ijb/10.4.222-231

Babula, P., Mikelova, R., Potesil, D., Adam, V., Kizek, R., Havel, L., Sladky, Z. 2005. Simultaneous Determination of 1,4-Naphtoquinone,
Lawsone, Juglone and Plumbagin by Liquid Chromatography with UV Detection. Biomedical Papers. 149(Supplement 1):25-28.

Badan Pusat Statistik Kota Palangka Raya. 2018. Jekan Raya Dalam Angka. Palangka Raya: Badan Pusat Statistik Kota Palangka Raya.

Darmosarkoro, W., Harahap, I.Y., Syamsuddin, E. 2001. Pengaruh Kekeringan pada Tanaman Kelapa Sawit dan Upaya Penanggulangannya. Warta PPKS. 9(3):83-96.

Firmansyah, M.A., Sudarsono, Pawitan, H., Djuniwati, S., Djajakirana, G. 2008. Characterization and Resilience of Upland Degraded Soils of Central Kalimantan. Jurnal Tanah dan Iklim. 27(1):22-32.

Naspiah, N., Iskandar, Y., Moektiwardoyo, M. 2014. Artikel Ulasan: Bawang Tiwai (Eleutherine americana merr.), Tanaman Multiguna. Indonesian Journal of Applied Sciences. 4(2):18-30. https://doi.org/10.24198/.v4i2.16820

Pusat Studi Biofarmaka LPPM IPB, Ulung, G. 2013. Sehat Alami dengan Herbal. Jakarta: Gramedia Pustaka Utama.

Rezaei, M.R., Abdoli, M.A., Karbassi, A., Baghvand, A., Khalilzadeh, R. 2010. Bioremediation of TNT Contaminated Soil by Composting with Municipal Solid Wastes. Soil and Sediment Contamination. 19(4):504-514. https://doi.org/10.1080/15320383.2010.48604 9

Setyawan, A.B., Budiman, A., Septiawan, T. 2019. Pembuatan Teh Bawang Dayak dan Manfaatnya Bagi Kader Pusat Kesehatan Masyarakat Harapan Baru Samarinda Seberang. PengabdianMu: Jurnal Ilmiah Pengabdian kepada Masyarakat. 4(2):68-73. https://doi.org/10.33084/pengabdianmu.v4i 2.812

Surianto, Rauf, A., Sabrina, T., Sutarta, E.S. 2015. Karakteristik Tanah dan Perbandingan Produksi Kelapa Sawit (Elais quinensis Jacq.) dengan metode tanaman lubang besar dan parid draenase 2:1 pada lahan spodosol di kabupaten Barito Timur provinsi Kalimantan Tengah. Jurnal Pertanian Tropik. 2(2):150-153. 